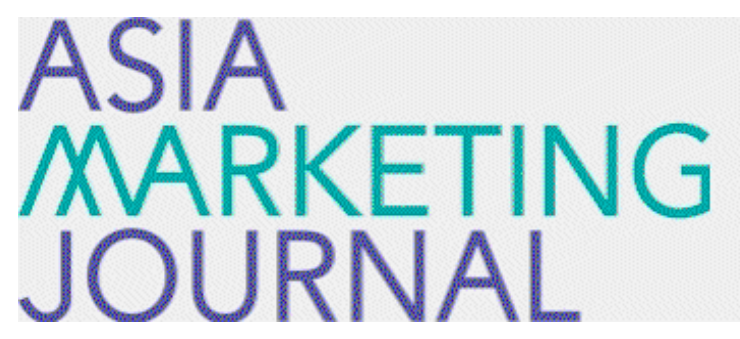

ASIA MARKETING JOURNAL

Volume 2 | Issue 3

Article 4

$9-1-2000$

\title{
신제품개발의 성공요인에 관한 연구
}

Sung Han Suh

Seo Hwan Cho

Follow this and additional works at: https://amj.kma.re.kr/journal

Part of the Marketing Commons

\section{Recommended Citation}

Suh, Sung Han and Cho, Seo Hwan (2000) "신제품개발의 성공요인에 관한 연 구," Asia Marketing Journal: Vol. 2 : Iss. 3 , Article 4.

Available at: https://doi.org/10.53728/2765-6500.1045

This Article is brought to you for free and open access by Asia Marketing Journal. It has been accepted for inclusion in Asia Marketing Journal by an authorized editor of Asia Marketing Journal. 


\title{
신제품개발의 성공요인에 관한 연구*
}

\section{A study of Key Success Factors in New Product Development -Focused on Korean Cosmetic Industry-}

\author{
서 성한(경희 대학교 경영대학원장) \\ suhsh@nms.kyunghee.ac.kr \\ 조 서환(경영학 박사/ 애경산업(주 마케팅담당 상무이사) \\ shcho@aekyung.co.kr
}

기업의 사활은 신제품개발의 성공여부에 달려 있다.

이러한 필요성과 중요성에 비추어블 때, 국내에서의 신제품 성공 요인에 관한 연구는 그 기반이 미흡한 실정이다. 고로, 본 연구의 목적은 신제품 성공요인을 파악하고 이들 성공요 인간의 관계률 유추해 보는 것으로 한다.

본 연구논문은, Day \& Wensley 의 SPP(Source-Position-Performance) 연구모형을 바탕으로 국내 화장품시장을 중심으로 설문 조사한 결과, 11 개 기업에서 총 159 부를 수집하여 연구 모형 및 연구 가설을 검중하였다. 그래서 다음과 같온 사실을 밝혀냈다.

첫째, 신제품개발 과정에서 마케텅 능력이 직접적으로 제품차별화에 긍정적인 영향을 미치 고 있다는 사실과 둘째, 임직원 몰입도가 부서간 통합에 유의한 영향을 미치고 있다는 사실 이다. 그리고 셋째, 기술 능력이 단순히 떠어나다 해서 제품을 차별화 시킬 수는 없다는 사 실과 넷째, 부서간 통합정도가 직접적으로 제품차별화를 가져울 수는 없었는데 이러한 결과 는 부서내 커뮤니케이션의 부족 및 부서간 갈둥 둥으로 인한 것으로 분석된다. 마지막으로, 제품의 차별화가 신제품 성과에 매우 유의한 영향을 미치고 있다.

본 연구결과를 종합해 보면, 제품이 출시되기 전에 철저한 시장 특성 및 동향을 파악하여 제품을 만들어야 한다는 사실이다. 기술 능력이 희사마다 평준화되어 있는 상황에서 무엇보 다 필요한 것은 정확한 소비자 조사 및 이를 바탕으로 한 신제품개발이다. 또한 신제품개발 과정에서 최고경영자 및 마케텅 담당자듈은 주관적인 판단보다는 기업의 마케팅 능력에 따 른 객관적인 판단에 따라 행동해야 한다.

톡히 화장품시장에서는 브랜드마케팅에 의해 더욱 차별화시킬 수 있다는 사실이다. 단순 한 제품에 생명력을 블어넣는 것이 마케터의 역할이다. 기업은 단순히 제품만을 파는 것이 아니라 소비자들에게 제품이상의 것을 판다. 그래서 소비자의 마음속에 정확하게 자사 제품 을 포지션넝하는 것이 무엇보다 중요하다는 사실이다.

논문접수: 00.09 게재확정: 01.01 


\section{1. 머리말}

기업의 사할은 신제품개발의 성공여부에 달려 있다. 쁙히 소비재용품(consumer goods)은 더욱 그렇다. 급속한 기술의 발전, 좁혀지는 기술 격차, 소비자 욕구의 세분화와 다양화, 짧아지는 제품 수명, 시장의 전면적인 개방 둥은 기업들을 무한 경쟁의 상태로 몰아넣어 기업들이 생존을 위해 신제품 개발에 집중하도록 만들었다. 따라서 많은 기업들은 신제품 성공을 위해 경쟁 우위를 보유한 신제품 개발에 막대한 투자를 하고 있다. 그러나 상당수의 경영자들은 신제품의 기술적 성공이 곧바로 상업적 성공으로 연결되는 것으로 인식하여, 신제품욜 개발할 때 신제품의 기술적 성공에만 집착하고 시장의 성공에 대해서는 상대적으로 관심이 적은 형편이다. 그러나 시장에서의 격렬한 경쟁 때문에 경쟁적 우위를 가진 즉, 기술적으로 성공한 신제품이라 할지라도 효과적으로 마케팅 노력을 수반하지 않으면 상업적으로 성공하기 어려운 것이 헌실이다. 이러한 필요성과 중요성에 비해 국내에서는 신제품의 상업적 성공 요인에 관한 연구 기반이 미홉한 실정이다(윤태석 1993).

본 연구논문의 목적은 기업의 측면에서 전반적으로 신제품 성공요인올 파악하고 이들간의 관계를 유추해 보는 것으로 한다. 그래서 개별 요인의 영향력은 측정하기 편리하고 개별요인 상호간의 관계도 웝게 고찰할 수 있을 것으로 판단되기 때문에 개별 신제품올 중심으로 한 기업전략 연구를 시행하였다. 이러한 관점에서 다음과 같은 문제점들을 밝혀보고자 한다.

첫째, 신제품 성공에 영향을 미치는 요인이 무엇인가를 파악한다. 기존연구들에서 제시된 신제품 성공 요인(key success factors)을 분류해 보고, 그 중요성에 관한 검토를 통해 의미 있는 요인들을 추출하여 재구성해 보고자 한다. 이와 관련하여 선행 연구에서 간과한 요인 및 변수는 없는가, 중복되는 것온 없는지를 확인한다.

둘째, 신제품 성공요인간의 상호관계를 파악한다. 대다수의 연구가 주로 신제품 성공요인과 신제품 성과간의 관계에 대해서만 관심을 보여왔기 때문에, 신제품 성공요인 상호간의 관계에 대해서는 이렇다 할 연구성과가 나와있지 못한 상태이다. 그러나 신제품성과가 단일요인의 단독적인 영향만으로 변화되는 것은 아닐 것이라는 가정하에 성공요인간에 상호관계를 파악하고, 이를 근거로 종합적인 신제품 성공의 관계모형을 제시해 보고자 한다.

마지막으로, 국내 기업들이 지향해야 할 신제품 전략의 방향은 무엇인가를 제시한다. 신제품 성공이 기업에 미치는 영향이 매우 크다고 할 수 있는데, 그 중요성에 비해 신제품 성공을 위해 기울이는 기업의 노력은 일부 요인에만 편중되거나 혹은 개별요인의 자발적인 영향력에만 초점을 두는 경향을 나타내고 있으므로 이를 수정하는데 도움이 되는 지침을 제시해 보고자 한다.

\section{2. 이론적 배경}




\section{1 신제품의 개념}

' 신제품' 에 대한 개념은 혁신의 정의에 바탕을 둔 것이므로 다양한 형태로 정의되고 있다. 대표적인 구분방법으로는 인식주체를 개인이나 소비자로 보는 관점과 기업으로 보는 관점이 있다.

소비자의 관점에 의하면 신제품은 ' 개인이나 소비자에 의해 새로운 것으로 인식되어지는 제품, 이라고 정의된다(Scheuing 1989). 그런데 이러한 정의는 다음과 같은 두가지 문제점을 내포하고 있다. 첫째, 새롭거나 색다른 것으로 인식되기만 하면 되기 때문에 고객으로서 제품자체가 새로운 것일 요소는 없다는 점이다. 둘째, 인식객체인 제품자체가 객관적으로 새로운 것입에도 불구하고 그렇게 인식되지 못한다는 이유만으로 신제품이 되지 못할 수도 있다는 점이다. 이외에도 연구 목적상 신제품의 범위를 제한시키고자 할 경우 미국의 연방거래위원회에서와 같이 출시 후 6 개월이내의 것만을 신제품으로 부르거나, 시장점유율 $10 \%$ 이하의 것만 신제품으로 규정하는 편법이 사용되기도 한다(Enge1, Blackwell, and Miniard 1990).

기업의 관점에 의하면 신제품은 광의로는 ' 특정기업에게 새로움이 있는 제품(Scheuing 1989)' 또는 ' 관계가 있는 기업에게 어떠한 방식이건 새로움이 있는 제품(김원수 1991)' 이라고 정의된다. 협의로는 ' 다른 제품이 지금까지 수행할 수 없었던 기능을 수행하는 제품' 또는 '기존의 형태와는 질적으로 다른 제품(Engel, Blackwell, and Miniard 1990)' 이라고 정의된다. 같은 맥락에서 '시장에서 이미 존재하나, 그 기업에게 전혀 새로운 제품을 새로 제조. 판매하계 되는 경우' 가 신제품의 개념이 되어야 한다는 견해도 있다.

이러한 두가지 관점의 정의가 모두 문제점을 지니고 있다는데 착안한 Booz, Allen and Hamilton(1982)은 기업에의 새로움과 시장에의 새로움이라는 변수를 함께 사용하여 신제품 분류의 룰을 제시하였다. 그러나 본 연구에서는 기업의 관점에서 본 신제품의 정의를 사용하여 분석하였다.

\section{2 신제품개발 관련변수 및 성과에 관한 연구}

\subsection{1 기업역량 및 자원과 관련된 요인}

기업역량 및 자원이 신제품개발의 성공에 미치는 영향에 관한 연구로는 Day \& Wensley(1988)가 기업의 경쟁력 원천(source of advantage)이 제품 차별화의 포지션상의 우위(positional advantage of product differentiation)를 가져오고 이것은 다시 신제품의 매출, 이익, 시장점유율 둥의 상대적 성과에 영향을 준다는 연구모형을 제시하였다. 이 연구모형을 토대로 Song \& Parry(1997)은 신제품개발 성공을 결정하는 경쟁력 원천으로 마케팅 역량 및 자원(marketing skills and resources), 기술 역량 및 자원(technical skills and resources), 및 부서간 통합정도(cross-functional integration) 둥을 제시하였다.

우선 기업의 역량 및 자원과 관련된 요인은 인적· 재무적- 물적 자원과 기업 활동의 강. 약점, 재무, 생산, $\mathrm{R} \& \mathrm{D}$, 인사 및 최고경영자 둥 경영관리 기능이 신제품 전랴을 얼마만큼 지원해 주는지와 관련된 것이다. 이와 관련하여 신제품 성공 요인 연구에서는 
다양한 요인들율 제시하고 있다. 이들 요인들을 크게 두가지로 요약하면 다음과 같다.

첫째, 최고경영자 차원의 요인으로서 최고경영자의 신제품 프로젝트에 관한 관심과 지원올 들 수 있다. 최고 경영자가 신제품 프로젝트에 관한 비전을 가지고, 정보와 신념을 제공해 주면서, 잘못은 희사에서 책임진다는 자세로 강력하게 추진할 때 프로젝트의 성공률은 높아질 것이다. 신제품개발의 성공을 위해서는 최고 경영자가 기꺼이 위헙부담올 감수하고 신제품으로부터 창출되는 이익의 불확실성울 인정해 주어야 하며, 한편으로 신제품에 대한 몰입도 및 신제품 성공에 대한 확고한 신념을 조직구성원들에게 알려줄 필요가 있다(Kuczmarski 1988). 신제품 성공 요인 연구에서도 이와 관련된 요인들을 많이 제시하고 있다. 주요 요인으로는 최고경영자의 관심 내지 물입정도, 최고경영자롤 포함한 기업 전반적인 지원, 기업 목적이나 기업자원과 신제품 프로그램의 적합성 등을 들 수 있다(김홍범 1986; Lilien \& Yoon 1989; Zirger \& Maidique 1990).

둘째, 조직 차원의 요인으로서 조직의 구조, 관련 기능 부서간 협려체계 둥을 들 수 있는데, 이러한 조직 차원의 요인이 신제품 성과에 미치는 영향만을 다룬 연구들도 있다. 이 범주에 속하는 요인 중 주요한 것으로는 기술-생산 시너지, R\&D-마케텅 시너지, 기능 부서간 협력 관계, 부서간 내부 커뮤니케이션 등이 있다(Hise et al. 1990).

\subsection{2 마케팅 역량 및 자원과 관련된 요인}

Crawford(1991)는 신제품 실패율을 정리· 분석한 연구에서 마케팅 지식 및 숙련도 요인과 마케팅 커뮤니케이션 및 진입노력 요인을 제시하고 있다. Cooper \& Kleinschmidt(1988)의 연구에서는 기존 연구에서 제시된 요인들을 정리하여 소비자 요구의 이해도, 시장 지식 및 마케팅 숙련도, 제품시장 정보 수집단계에 대한 관심도, 진입노력의 강도의 4 가지 요인을 제시하고 있다. 이 중 진입노력은 판매 및 촉진활동에의 물입도 및 숙련도를 의미하는 것으로 주장하였다. 김훙범(1986)의 연구에서도 앞의 두 연구들과 거의 유사한 요인들을 제시하였다.

Kodama(1995)는 NPD 에서 가장 중요한 요소는 소비자의 니즈(Needs)를 잘 정립된 제품으로 변환시키는 능력이라고 하였다. 이 요소는 두 단계의 프로세스로 구성되어 있다. 시장 데이터(market data)를 제품 컨셉화(product concept) 하는 눙력과 제품 컨셉을 제품개발 프로젝트로 재구성하는 능력이다. Kodana 는 이러한 프로세스능력을 잘 갖추고 있는 일본기업의 톡성을 다음과 같이 세가지로 요약하였다. 첫째, 최고경영자가 NPD 에 대한 장기적인 비전 - NPD 과정에서 필요한 재원을 할당하는 능력 - 을 가지고 있다. 둘째, 기업이 활동하고 있는 산업전반에 걸쳐 상당한 기술적 능력이 축적되었고, 다른 산업의 기술을 홉수. 통합할 수 있는 능력도 상당히 보유하고 있다. 셋째, 기업돌은 기업간 경쟁이 매우 치열하여 소비자의 욕구 만족과 그에 따른 독븍한 제품개발에 상당한 관심을 보이고 있다.

\section{2 .3 기술 역량 및 자원과 관련된 요인}

기업이 현재 보유하고 있는 기술 역량 및 자원이 신제품을 개발하는데 매우 유용한 요인이다(Cooper 1979). 기술 역량 및 자원이 뛰어나다면 기업은 경쟁사보다 실제 
제품사용에 있어서 경쟁적인 이점을 가질 수 있다. 기술역량 및 자원의 보유는 Calantone, Schmidt, and Song(1996)과 Song \& Parry(1997)의 연구논문에서도 제품 차별화에 매우 긍정적인 영향율 미치는 요인으로 제시되었다.

\section{2 .4 제품 특성과 관련된 요인}

신제품 성공 요인에 관한 연구에서 제시된 제품 톡성 관련 요인들은 매우 다양하며, 경우에 따라서는 개념상의 중복을 보이기도 한다. Cooper(1979)는 18 개의 요인을 추출하여 이를 실중 분석한 결과 성과에 미치는 영향력이 가장 큰 것으로 밚혀진 요인으로 제품 독특성 및 우월성 요인을 제시하였다. 이 요인의 구성 변수로는 혁신성, 형태의 특이성, 소비자 요구 충족도, 소비자 비용 절감성, 과업의 특이성, 고품질 수준 등이 사용되었는데, 이 중에서 소비자 요구 충족도, 형태의 독특성, 고품질 수준이 특히 영향력이 큰 것으로 나타났다.

Cooper \& Kleinshmidt(1987)의 연구에서도 제품 우월성, 제품 품질, 톡이한 편익의 3 가지 변수가 주요 변수로 나타났는데 한가지 문제점은 변수의 조작적 정의상 두 연구간의 차이가 나타나고 있다는 점이다. 후자의 연구에서는 제품 우월성을' 소비자 관점에서 본 경쟁제품 대비 제품의 우월성' 으로 정의하고 나머지 변수와 같은 수준의 것으로 다루었는데 반해, 전자의 연구에서는 제품의 우월성을 여러 가지 변수를 통합한 하나의 요인으로 보고 있었다는 점이다. Lilien \& Yoon(1989)의 연구에서는 사용자 편익 및 경제적 우위(기눙적 속성), 상대적 우월성 및 독특성(형태적 속성)이 중요한 요소로 인식되었다.

그리고 NPD 와 관련한 많은 연구문헌에서, 제품 차별화가 신제품 성공의 중요한 결정요인으로 파악되었다. 예를 들면, 유럽과 일본 기업을 중심으로 신제품개발 프로젝트를 비교. 연구한 Utterback et. al.(1976)은 성공적인 신제품개발 프로젝트는 확고한 경쟁우위률 확보할 수 있는 제품을 만들어야 한다고 하였다. Cooper(1979)와 Song \& Parry(1994)는 신제품의 성공정도와 제품차별화 -독톡한 제품의 특성, 상대적 고품질의 제품, 소비자 비용 절감 효과, 소비자 가치- 가 상당한 상관관계가 있다고 하였다. Maidique \& Zirger(1984)는 신제품성공의 수익성과 제품의 고기능성 대비 비용에 관한 연구 및 소비자에 대한 가치와 신제품성공에 관한 연구에서 유의한 결론을 도출하였다.

\section{2 .5 시장과 관련된 요인}

기존 연구에서 신제품 성과에 미치는 영향이 률 것이라고 제시된 시장 관련 요인 중 가장 일반적인 것은 시장의 규모와 성장 정도이다. 이와 유사한 것으로서 해당 제품 유형에 대한 소비자의 요구가 얼마나 강한가를 나타내는 소비자 요구 수준을 제시한 연구도 있다(Cooper 1979; 김홍범 1986; Cooper \& Kleinschmidt 1987).

이 외에도 시장의 동태성을 나타내 주는 신제품의 도입 빈도, 소비자 요구의 변화 정도 등의 요인과 시장예 대한 경헙의 축적 여부를 나타내 주는 시장의 새로움의 정도와 같은 요인도 제시되고 있다(Cooper 1979; Cooper 1986; Cooper \& Kleinshmidt 1987; Sumita et al. 1998). 
Gatignon \& Xuereb(1997)은 시장수요가 불확실할수록 보다 기술 지향적이고 고객 지향적인 기업이 줗은 신제품개발 성과를 달성함을 보였다(김종배 1991; 노전표 1998). Han et al.(1998)은 시장의 격동성(market turbulence)과 기술의 격동성(technical turbulence)으로 대변되는 기업외부환경의 불확실성이 높을수록 기업의 시장지향성과 기업의 혁신성향의 긍정적인 관계가 강화된다는 사실을 주장하였다.

\section{2 .6 신제품 성과와 관련된 요인}

김종배(1998)는 신제품의 성과 및 측정에 관한 관점을 다음과 같이 분류하고 있다. 첫째, 신제품 성과을 측정하는 차원에 따라 개별 제품수준과 기업 전체의 신제품 수준으로 그 연구유형을 나누었다. 개별 제품 차원에서의 연구(project-based studies)는 기업관리 측면에서 특정한 개별 신제품의 개발 및 도입에 대하여 어떠한 행위가 이루어졌는지를 파악하여 이들 요인들과 제품 성과와의 관계가 통계적으로 유의한지를 연구하는 것이다(Cooper 1987).

반면, 전체 신제품 성과차원(firm level)의 연구는 기업의 전반적인 신제품 경영과 여건을 조사해 본 다음, 일반적인 요인들을 이용하여 전체적 신제품 성과와 관련시켜 보는 것이다(Cooper 1984). 둘째, 개별 제품 차원에서의 연구는 연구대상의 성격을 중심으로 하여, 성공한 신제품만을 대상으로 이들에게 공톻적으로 나타나는 특성을 찾고자하는 연구(Roberts \& Burke 1974)와 실패한 제품들만올 대상으로 실패한 이유를 분석하는 연구(Hopkins \& Bailey 1971; Cooper 1975), 그리고 성공한 제품과 실패한 제품을 서로 비교하면서 성공과 실패를 결정짓는 요인을 찾는 연구(Rothwell 1972, 1974; Cooper 1979; Maidique \& Zirger 1984, 최수호 1994; 김지태 1995; 채서일 1996; 최원일 1997)로 나누어 볼 수 있다. 쳇째, 총괄적 연구(generalist study)와 각론적 연구(specialist study)로 나누어 볼 수 있다(Craig \& Hart 1992). 총괄적 연구는 개별 신제품 및 기업 전체의 신제품 성과에 영향을 미치는 변수들의 전반적 집합에 초점올 맞춘다. 이러한 연구의 목적은 성과에 영향을 미치는 변수들을 파악하는데 있다(Rothwell 1972; Cooper 1979; Cooper \& Kleinschmidt 1987; 김종배 1998).

\section{3. 실중연구}

\section{1 연구모형}

경쟁우위(competitive advantage)에 관한 연구에서, Day \& Wensley(1988)는 마케팅, R\&D 및 생산 부서의 역량과 재원(skill and resource)이 비용/제품 차별화의 측면에서 기업의 경쟁우위에 미치는 상관관계를 살펴보았다. 또한 비용/제품의 차별화가 기업의 성과측정 고객만족, 충성도, 시장점유율, 수익성 - 에 영향을 미친다는 사실을 밝혔다. 이러한 연구체계는 신제품성공의 결정요인에 관한 최근의 문헌들울 조망해 보는데 많은 시사점을 주고 있다. 예를 들면, 신제품 성굥과 (1) 기업의 마케팅 역량 및 자원, (2) 기술적 역량 
및 자원과 상당한 정(t)의 상관관계가 있는 것으로 밚혀졌다(Cooper 1979; Cooper \& Kleinschmidt 1987; Parry \& Song 1994; Calantone, Schmidt, and Song 1996; Song \& Parry 1996).

신제품개발에 관한 연구논문에서 주목할 만한 것이 부서간 통합정도가 제품의 차별화의 관계를 매개하는 요인에 관한 것이다(Day \& Wensley 1988; Calantone, Schmidt, and Song 1996). 또한 신제품성공에 있어서 다양한 마케팅 활동이 중요한 변수로 인식되었고(Rothwell et al. 1974; Utterback et al. 1976; Maidique \& Zirger 1984), 제품의 차별화와 신제품 성과간 관계에서 환경에 관한 변수가 조절변수로서 영향을 미쳤다는 사실이다(Cooper 1979; Cooper \& Kleinschmidt 1987, 1993). 본 연구논문에서는 국내 화장품시장올 중심으로 NPD 의 전반에 걸친 프로세스를 파악하고자 <그립 3-1>과 같은 연구모형을 설정하였다.

<그림 3-1> 연구모형

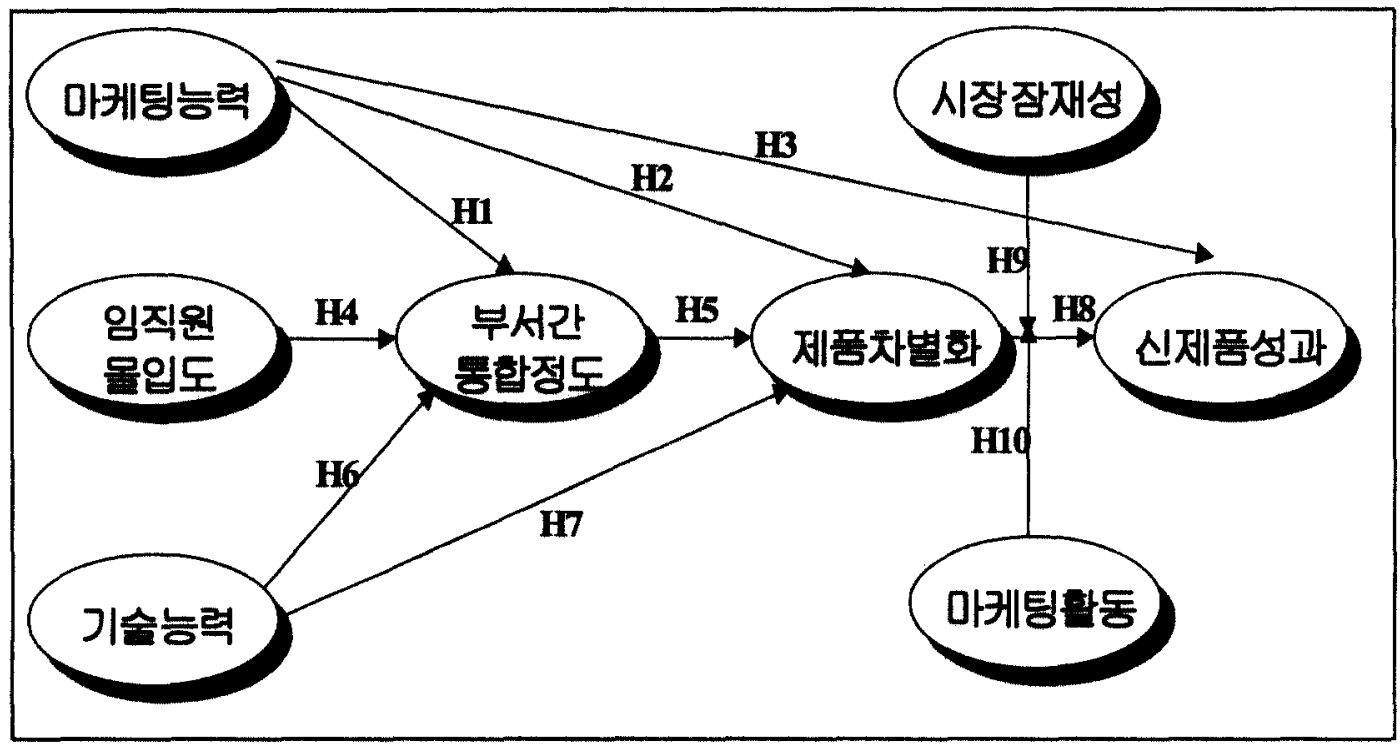

3.2 가설 설정

\section{2 .1 제품의 차별화에 관한 가설 설정}

$\mathrm{NPD}$ 와 관련된 기존 연구를 살펴보면, 다양한 신제품개발 활동이 신제품 성공에 주요한 결정요소라는 사실을 알 수 있다. 예를 들면, Rubenstein et al.(1976)은 54 개의 신제품 프로젝트률 연구한 결과, 데이터률 수집· 분석하고 의사결정을 내리는데 월둥한 능력을 보유한 기업일수록 신제품의 성공 가능성이 높았다고 주장하였다(Day \& Nedungadi 1994; Maidique \& Zirger 1984). Cooper(1979)와 Song \& Parry(1994)의 연구논문에서도 신제품의 성공과 제품개발에 관련된 기업의 부서간 퉁합에 정(+)의 관계가 있음을 알 수 있다. 이러한 마케팅 정보는 제품의 상품화에 대한 방향을 제시해 주고, 타사의 동일 컨셉 제품과의 차별성을 부각시킬 수 있는 능력을 고양시키며, 마케텅 역량 및 자원을 
효과적으로 사용하는데 유용하게 사용될 수 있기 때문이다. 즉 신제품개발 과정에서 마케팅 능력이 제품을 차별화하는데 중요한 역할을 하고 있음을 알 수 있다. 다옴과 같은 가설 I , II , III을 설정하였다.

가설 I 신제품개발 과정에서 기업의 마케팅 눙력이 부서간 풍합에 긍정적인 영향을 미칠 것이다.

가설 Iㅡ 신졔품개발 과정에서 기업의 마케팅 능력이 제품 차별화에 긍정적인 영향을 미칠 것이다.

\section{가설 프 신제품개발 과정에서 기업의 마케텅 능력이 신제품 성과에 긍정적인 영향을 미칠 것이다.}

임직원의 몰입도(internal commitment)는 신제품개발 프로젝트를 성공적으로 완수(completion)하여 신제품을 상업화(commercialization)하는데 대한 기업내 구성원의 참여를 말한다. 기업내 구성원들은 최고경영자, 마케팅 담당 중역, 프로젝트 리더, 프로젝트팀원으로 구성되어 있다(Zirger \& Maidique 1990; Griffin \& Hauser 1992; 1993). 신제품 프로젝트에 참여하고 있는 조직구성원들은 그들이 담당하고 있는 프로젝트가 기업 내에서 우선권(priority)이 있어서 기업의 자원을 원활히 활용 할 수 있다고 생각하며, 프로젝트 수행시 발생되는 난관을 돌파하고자 노력한다. 일본의 신제품개발에 대한 연구문헌에서 알 수 있듯이, 조직구성원의 몰입정도가 신제품개발에서 중요한 요인으로 인식되었다(Clark \& Fujimoto 1990, 1991; Imai et al. 1985).

NPD 에 관련한 수많은 연구논문에서, 부서간 통합정도가 정보전달(Ruekert \& Walker 1987)과 문제해결(Clark \& Fujimoto 1990; Nonaka 1990)에 중요한 메커니즘으로 파악되었다. 부서간 퉁합정도가 높을수록 프로젝트팀원들이 정보률 수집·전달하는데 용이하여, 제품디자인과 제품 테스팅과 같은 신제품개발 활동이 원활하게 진행될 수 있다. 다옴과 같은 연구가설 $\mathrm{IV}, \mathrm{V}$ 를 설정하였다.

가설 IV 신제품개발 과정에서 기업 내 임직원 를입도는 부서간 풍합정도에 긍정적인 영향을 미칠 것이다.

가설 V 신제품 개발에 대한 기업 내 부서간 뿡합이 높을수톡 제품차별화는 커절 것이다.

성공적인 신제품은 기업에 존재하고 있는 능력(capabilities), 역량(skills)과 
자원(resources)의 총체적 결합에 의해 창출된다(Day \& Wensley 1988; Stalk 1988; Prahalad \& Hamel 1990; Clark \& Wheelwright 1992; Shulman et al. 1992). 기업 특유의 기술(firm-specific techniques), 시장 및 경쟁사의 정보에 대한 이해, 지식을 창출하고 전파하는 문화창조가 NPD 를 효과적으로 운영하는데 필요하다(Preffer \& Salancik 1978). 즉 기업이 보유하고 있는 기술적 강점(technical strength) 여부가 신제품개발에 있어서 매우 중요한 요소이다. 기업의 기술적인 역량 및 자원이 신제품개발에 적합하다면, NPD 과정에서 기업의 활동이 원활하게 이루어지게 된다(Cooper 1979). 그래서 기업의 신제품개발이 경쟁사보다 뛰어나게 수행된다면, 제품을 차별화 시키는데 매우 유용할 것이다(Calantone et al. 1996; Song \& Parry 1997). 그래서 본 연구에서는 다음과 같은 연구가설 VI, VII을 설정하였다.

가설 VI 신재품개발에 대한 기업의 기술능력이 부서간 풍합에 긍정적인 영향을 미칠 것이다.

가설 VII 신제품개발에 대한 기업의 기술능력이 뷔어날수툭 제품 차혈화는 커질 것이다.

3.2 .2 신제품 성과에 관한 가설 설정

SPP 모형은 제품의 차별화룔 신제품 성과와 관련지어 설명하고 있다. 즉 경쟁사와 차별화된 제품은 고객만족과 고객의 충성도률 강화시킬 수 있는 잠재성을 지님을 가정하였기 때문이다(Day \& Wensley 1988). 이 모형을 토대로 하여 수행된 연구논문에서도, 제품의 차별화가 신제품 성공에 매우 연관되어 있옴을 알 수 있다(Cooper \& Kleinschmidt 1987, 1993; Parry \& Song 1994, 1996). 그래서 본 연구논문에서도 다음과 같은 가설 VIII을 설정하였다.

\section{가설 VIII 신제품 개발에서 수행된 차별화둰 제품은 신제품 성가에 궁정적인 영향을 미칠 것이다.}

한편, Day \& Wensley(1988)는 제품의 차별화가 신제품 성궁에 미치는 영향은 몇 가지 요인들에 의해 차이가 있음을 밝혔다. 즉 조절변수로서 다음과 같은 두 가지 요소들이 있었다; 마케팅 활둥과 관련된 변수와 환경과 관련된 요소, 우선, 제품의 차별화와 신제품 성과를 강화시킬 수 있는 요인으로 환경요인 - 시장의 잠재성-이 있다. 시장의 잠재성이란 시장의 크기와 성장 가능성과 같은 시장 특성을 반영하는 목표시장에 대한 유인정도를 말한다. 그러므로 시장의 잠재성이 클 때, 신제품 매출액, 점유율과 수익성이 중대된다(Cooper 1979; Song \& Parry 1994). 본 연구논문에서도 화장품시장에서는 틈새시장을 공랴하여 제품을 생산할 경우 잠재시장이 매우 크다는 점을 감안하여 다음과 같은 가설 $\mathrm{IX}$ 를 설정하였다. 
가설 IX 시장의 잠재성이 높을수톡 제품의 차별화가 신제품 성과에 긍정적인 영향을 미칠 것이다.

둘째, 기업의 마케텅 노력은 신제품울 시장에 출시한 후, 소비자들의 구매행동에 영향을 미칠 수 있다는 것이다(Song \& Parry 1997). 그래서 본 연구논문에서도 이러한 마케텅 측면에서 차별화된 제품이 시장에서 성공할 수 있다는 생각에서 다음과 같은 가설 $\mathrm{X}$ 을 설정하였다.

가설 $\mathrm{X}$ 기업이 수행하는 마케텅 노력이 를수톡 제품의 차별화가 신제품 성과에 긍정적인 영향을 미칠 것이다.

\section{3 변수의 정의 및 조사설계}

\subsection{1 변수의 조작적 정의(operational definition)}

측정변수(measurement items)들은 기존의 문헌에서 추출하여 본 연구의 목적에 사용되었다(Cooper 1979; Calantone \& Cooper 1981; Zirger and Maidique 1984, 1990; Cooper \& Kleinschmidt 1986, 1993; Parry \& Song 1994; Song \& Parry 1994, 1996). 그리고 모든 측정변수들온 7 점 척도(1 점: 매우 그렇지 않다 -7 점: 매우 그렇다)로 이루어졌다. 본 연구논문에서 설정된 요인 및 변수들의 조작적 정의를 살펴보면 다음과 같다.

(1) 마케팅 능력

제품 차별화(product differentiation)가 신제품개발에 있어서 중요하기 때문에, 신제품개발 과정에 마케팅 능력을 두 가지 구성개념으로 나누어 측정하였다. 첫째, 신제품 아이디어 개발에 관한 구성개념으로 세가지 변수들을 가지고 측정하였다. 즉 신제품 아이디어률 제품 컨십으로의 변환 능력, 사업가능성 판단여부, 실제적인 신제품개발- 제조 가눙성 여부였다. 둘째, 시장기희 분석 구성개념으로 다섯가지 변수들로 측정하였다. 즉 소비자 욕구, 시장톡성 몇 경향 파악, 재무적인 재원, 정보수집 및 분석능력, 경쟁 제품의 특성 및 마케팅 전략이었다(Cooper \& Kleinschmidt 1987; Urban \& Hauser 1993).

(2) 마켸팅 할동

마케팅 활동은 신제품이 출시된 후 기업이 신제품에 기울이는 것을 말한다. 본 연구에서는 마케텅 활동을 다음과 같이 측정하였다. 이 요인은 크게 다섯가지 변수들로 측정하였다. 즉 유퉁, 광고/판촉, 브랜드 관리, 소비자 반옹정도, 출하시기였다(Cooper 1979). 
(3) 기술 능력

기술 능력(technical proficiency)은 기업이 가지고 있는 기술 역량(capabilities)이 신제품개발 프로젝트에 부합하는 정도블 말한다. 이 구성개념은 세가지 변수로 측정되었다. 즉 R\&D 및 생산능력, 생산설비 능력, pilot test 여부였다(Cooper 1979).

(4) 임직원 몰입도

임직원 몰입도(internal commitment)란 신제품 프로젝트의 성공에 대한 조직구성원의 헌신적인 노력을 말한다. 이 구성개념온 네가지 변수들로 측정하였다. 즉 상위경영자들의 몰입정도, 신제품 프로젝트팀의 몰입수준, 신제품개발에 따른 회사내 보상체계, 신제품 성공 확신정도였다(Cooper 1979).

(5) 부서간 퉁합정도

부서간 퉁합정도(cross-functional integration)란 신제품을 개발하고 시장에 출시하는데 있어서 부서간의 노력을 의미한다. 이 구성개념은 네가지 변수로 측정되었다. 즉 R\&D생산부서, 마케팅-생산 부서, 마케팅-R\&D, 마케팅-디자인 부서간 상호협조였다(Maidique \& Zirger 1990).

(6) 제품 차별화

제품차별화(product differentiation)란 동일 컨셉 경쟁 제품과 비교하여 제품의 인지된 우월성(perceived superiority)을 의미한다. 이 구성개념은 5 가지 변수들로 측정되었다. 즉 시장의 새로움, 시장의 변화, 소비자 가치, 고품질, 혁신적인 제품 여부였다(Cooper 1979; Zirger \& Maidique 1990).

(7) 시장 잠재성

시장 잠재성(market potential)은 기업의 신제품이 목표로 한 시장에서 잠재적인 수요를 증대시킬 수 있는 여부를 의미한다. 이 구성개념은 3 가지 변수를 가지고 측정하였다. 즉 잠재적 소비자 존재, 소비자 욕구 정도, 시장 성장성이었다(Cooper 1979, Song \& Parry 1997).

(8) 신제품의 성과

신제품의 성과(performance)-기업의 주관적인 측면-를 측정하기 위해, 본 연구에서는 세 가지 요인(factor)을 사용하였는데 수익성(relative profitability), 시장점유율(relative market share), 판매성과(relative sales) 요인들이 그젓이다. Song \& Parry(1997)의 연구논문에서도, 신제품의 성과를 기업의 주관적인 관점(subjective scales)에서 측정하였다. Song \& Parry는 미국과 일본기업에 대한 36 개의 심충 사례연구(in-depth case studies)와 표적집단 면접법(FGI)을 퉁해 신제품의 성과에 대한 기업의 주관적인 척도로도 동일 산업내 기업간 흑온 기업내 신제품과 비교가 가능하다고 판단하였기 
때문이었다(Jaworski \& Kohil 1993; Olson, Walker, and Ruekert 1995). 그리고 본 연구에서도 국내 기업 환경상 객관적인 자료는 외부로 유출되지 못하게 되어 있기 때문에 주관적인 관점에서 웅답자들이 각 요인들을 측정하도록 설계하였다.

\section{3 .2 표본선정의 이유와 자료수집}

본 연구논문을 수행하기 위해 국내 화장품시장을 중심으로 최근 3 년 이내에 신제품을 시장에 출시한 경협이 있는 웅답자(subjects)들을 표본으로 선정하였다. 본 연구자는 소비재 산업, 특히 국내 화장품시장을 중심으로 매우 치열하게 전개되고 있는 신제품개발 노력이 본 연구논문을 수행하기에 적합하다고 생각하여 표본을 선정하였다.

국내 화장품업계 12 개회사의 마케팅 담당 실무자와 접촉하여, 설문지를 우편 또는 직접 방문하여 자료를 수집하였다. 2000 년 3 월 6 일 - 2000 년 4 월 15 일까지 12 개 회사에 보낸 200 여 개의 설문지 중에서 11 개 희사에서 165 개의 설문지를 회수하였다. 그러나, 회수된 설문지 중에서 성실하게 웅답하지 않았거나, 결측치(missing value)가 있는 설문지률 제거한 후 본 연구에 이용 가능한 설문지는 총 159 부였다. <표 3-1>는 본 연구에 사용될 표본의 인구통계학적 특성을 보여주고 있다.

<표 3-1> 표본의 인구통계학적 특성

1)근무 부서

\begin{tabular}{ccc}
\hline 근무 부서 & 옹답자수 & 비 율(\%) \\
\hline 디자인 & 33 & 20.8 \\
마케텅 & 88 & 55.3 \\
생산 & 4 & 2.5 \\
영업 & 8 & 5.0 \\
R\&D & 18 & 11.3 \\
무웅답 & 8 & 5.0 \\
\hline
\end{tabular}

2)근무연수

\begin{tabular}{|c|c|c|}
\hline 근무 연수 & 웅답자수 & 비율 (x) \\
\hline 1년 5년미만 & 91 & 57.2 \\
\hline 5년 10년미만 & 39 & 14.6 \\
\hline 10년 15년미만 & 11 & 6.9 \\
\hline 15년 20년미만 & 4 & 2.5 \\
\hline 무웅답 & 14 & 8.8 \\
\hline
\end{tabular}




\section{4. 실중분석}

\section{1 요인분석 및 신뢰성 검중}

신뢰성 검중에 앞서, 본 연구의 구성개념에 대하여 탑색적 요인분석을 실시하였다. 요인 사이의 독립성을 가정하지 않는 사각회전(oblique)에 의한 요인분석 결과는 <표 4-1>에 나타나 있다. 이 매 평가기준으로서 요인 적재값 0.3 이상, 요인의 설명력(the variance extracted)은 0.5 이상을 설정하였다.

측정도구의 신뢰성이란 측정문항간의 내적일관성(internal consistency)을 의미하는 것으로 측정변수의 진정한 값을 측정할 수 있는 정도라 할 수 있다(Hair, Jr et al. 1995). 만일 동일한 측정도구를 이용해 동일한 개념(construct)을 반복적으로 측정하였을 때, 일관된 값을 나타낸다면 이는 신뢰성이 높은 측정도구라고 할 수 있다. 반면, 타당성(validity)이란 측정도구가 연구하고자 하는 개념을 올바르게 측정할 수 있는 정도로서 연구자의 연구목적에 의해 상당히 좌우될 수 있다. 이는 변수의 정의가 주로 연구자의 의도에 의해 결정되기 때문이다.

다항목 측정도구를 이용하는 경우에는 문항이 의도한 변수를 정확하게 측정하고 있는가를 확인하기 위해 반드시 측정도구의 신뢰성과 타당성을 분석하게 된다. 퉁계적으로 측정도구의 신뢰성은 주로 크론바하 알파값으로 평가한다. 일반적으로 알파값이 0.6 0.9 여야 만이 설문의 신뢰성이 보장되지만(Van de Van \& Ferry 1979), 새로이 개발된 설문의 경우는 최저 허용치 0.6 올 최저 허용치로 사용하기도 한다(Nunnally 1978). <표 4$2>$ 는 신뢰성 검중을 보여주고 있다.

<표 4-1> 탑색적 요인분석

\begin{tabular}{|c|c|c|c|c|c|c|c|}
\hline \multirow[b]{2}{*}{ 항목 } & \multicolumn{7}{|c|}{ 요인명 } \\
\hline & $\begin{array}{l}\text { 마케뗭 } \\
\text { 능젹 }\end{array}$ & $\begin{array}{l}\text { 기슬 } \\
\text { 눙멱 }\end{array}$ & $\begin{array}{l}\text { 입직원 } \\
\text { 굴입도 }\end{array}$ & $\begin{array}{l}\text { 푸서간 } \\
\text { 풍합경도 }\end{array}$ & $\begin{array}{l}\text { 졔푬 } \\
\text { 차년화 }\end{array}$ & $\begin{array}{l}\text { 시장 } \\
\text { 잠재성 }\end{array}$ & $\begin{array}{c}\text { 마켸텅 } \\
\text { 왈둥 }\end{array}$ \\
\hline $\begin{array}{c}\text { 사엄 가능성 } \\
\text { 여부 }\end{array}$ & 0.731 & & & & & & \\
\hline $\begin{array}{c}\text { 실재젹인 } \\
\text { 개발 가농성 }\end{array}$ & 0.640 & & & & & & \\
\hline 소비자 왁구 & 0.550 & & & & & & \\
\hline $\begin{array}{c}\text { 시장 댁셩 } \\
\text { 및 경향 }\end{array}$ & 0.720 & & & & & & \\
\hline 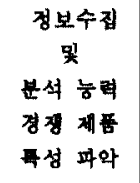 & 0.655 & & & & & & \\
\hline
\end{tabular}




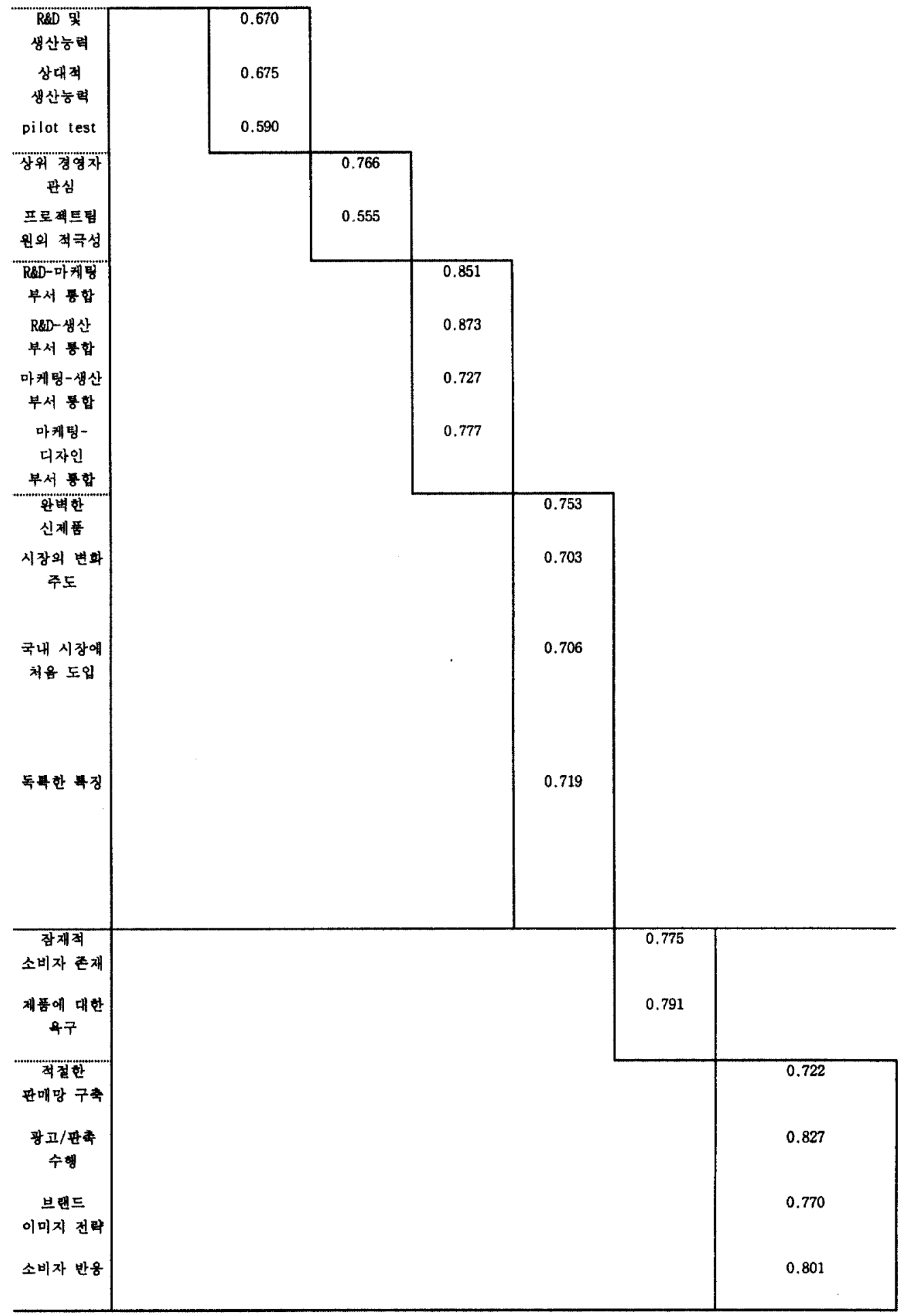

추츨방법 : Principal Component Analysis.

회전방법 : Varimax with Kaiser Normalization. 
<표 4-2> 전체 연구단위들에 대한 신뢰도 측정

\begin{tabular}{|c|c|c|}
\hline 구성개녑 및 항목 & $\begin{array}{c}\text { 전쳬 구성개념과 } \\
\text { 상관계수 }\end{array}$ & 신뢰도(Alpha) \\
\hline 마케텅 능력 & - & 0.8584 \\
\hline $\begin{array}{l}\text { 사업 가눙성 여부 } \\
\text { 실제적인 개발 가능성 } \\
\text { 소비자 욕구 } \\
\text { 시장 특성 및 경향 } \\
\text { 정보수집 및 분석 눙력 } \\
\text { 경쟁 제품의 마케팅전략 }\end{array}$ & $\begin{array}{l}0.6064 \\
0.5509 \\
0.6262 \\
0.7339 \\
0.6971 \\
0.6649\end{array}$ & \\
\hline 기술 능력 & - & 0.7479 \\
\hline $\begin{array}{l}\text { 개발 및 생산능력 } \\
\text { 상대적 생산능력 } \\
\text { pilot test }\end{array}$ & $\begin{array}{l}0.5551 \\
0.5523 \\
0.6204\end{array}$ & \\
\hline 입직월 믈입도 & - & 0.7778 \\
\hline $\begin{array}{l}\text { 상위 경영자의 관심 } \\
\text { 프로젝트팀원의 적극성 }\end{array}$ & $\begin{array}{l}0.6402 \\
0.6402\end{array}$ & \\
\hline 부서간 풍합정도 & - & 0.9024 \\
\hline $\begin{array}{l}\text { R\&D-마케팅부서퉁합 } \\
\mathrm{R} \& \mathrm{D} \text {-생산부서붕합 } \\
\text { 마케팅-생산부서통합 } \\
\text { 마케텅-디자인부서퉁합 }\end{array}$ & $\begin{array}{l}0.8334 \\
0.8554 \\
0.7208 \\
0.7227\end{array}$ & \\
\hline 재품 차녈화 & - & 0.8315 \\
\hline $\begin{array}{l}\text { 완벽한 신제품 } \\
\text { 시장의 변화 주도 } \\
\text { 국내 시장에 처음 도입 } \\
\text { 독특한 특징 }\end{array}$ & $\begin{array}{l}0.5170 \\
0.7450 \\
0.7018 \\
0.7116\end{array}$ & \\
\hline
\end{tabular}




\begin{tabular}{|c|c|c|}
\hline 구성개념 및 항목 & $\begin{array}{c}\text { 전쳬 구성개념과 } \\
\text { 상관계수 }\end{array}$ & 신뢰도(Alpha) \\
\hline 시장 잠재성 & - & 0.9045 \\
\hline $\begin{array}{l}\text { 잠재적 소비자 존재 } \\
\text { 제품에 대한 욕구 }\end{array}$ & $\begin{array}{l}0.7528 \\
0.8018\end{array}$ & \\
\hline 마케텅 할동 & - & 0.8919 \\
\hline $\begin{array}{l}\text { 적절한 판매망 구축 } \\
\text { 광고/판촉 수행 } \\
\text { 브랜드 이미지 전략 } \\
\text { 소비자 반웅 }\end{array}$ & $\begin{array}{l}0.6771 \\
0.7993 \\
0.7654 \\
0.8225\end{array}$ & \\
\hline 신제품 성과 & $\overline{-}$ & 0.9486 \\
\hline $\begin{array}{l}\text { 자사 다른 제품 대비 수익성 } \\
\text { 타사 동일 컨셉 제품 대비 수익성 } \\
\text { 회사 수익 목표 대비 성공성 } \\
\text { 자사 제품 대비 M/S } \\
\text { 타사 동일 컨셉 제품 대비 M/S } \\
\text { 회사 시장점유율 목표 대비 성공성 } \\
\text { 자사 다른 제품 대비 판매율 } \\
\text { 타사 동일 컨셉 대비 판매율 } \\
\text { 회사 판매성과 대비 성공성 }\end{array}$ & $\begin{array}{l}0.6858 \\
0.6549 \\
0.7131 \\
0.8048 \\
0.8615 \\
0.8838 \\
0.8566 \\
0.8319 \\
0.8725\end{array}$ & \\
\hline
\end{tabular}

\section{2 확인요인분석}

신뢰성 분석을 마친 후 측정항목들에 대하여 연구 단위별로 측정모델을 도출하기 위해서 확인요인분석을 실시하였다. 확인요인분석은 특정가설을 설정하고 이 자료에서 관찰되는 관계를 어느 정도 잘 설명하고 있는지의 정도률 나타내는 기법으로 분석과정에서 연구자는 사전지식이나 이론적인 결과를 가지고 가설형식으로 모형화하고 행렬의 일부원소의 값을 제약한다. 확인요인분석 결과, $\mathrm{x}^{2}=104.23, \mathrm{df}=41, \mathrm{p}=0.0000, \mathrm{GFI}=0.89, \mathrm{CFI}=0.90$, $\mathrm{IFI}=0.90$ 등으로 적합도가 높게 나타났다. 
<표 4-3> 확인.요인분석

\begin{tabular}{c|c|c|c}
\hline 구성개념 & 항목 & MSC & T값 \\
\hline \multirow{4}{*}{ 마케팅 눙력 } & 사업 가눙성 여부 & 0.61 & 8.04 \\
\cline { 2 - 4 } & 실제적인 개발가눙성 & 0.57 & 7.47 \\
\cline { 2 - 4 } & 소비자 욕구 & 0.75 & 10.63 \\
\cline { 2 - 4 } & 시장 특성 및 경향 & 0.82 & 11.98 \\
\cline { 2 - 4 } & 정보수집 및 분석 눙력 & 0.76 & 10.70 \\
\cline { 2 - 4 } & 경쟁 제품 븍성 파악 & 0.74 & 10.40 \\
\hline \multirow{3}{*}{ 기술 눙력 } & R\&D 및 생산능력 & 0.69 & 8.73 \\
\cline { 2 - 4 } & 상대적 생산눙력 & 0.66 & 8.21 \\
\cline { 2 - 4 } & Pilot Test & 0.77 & 9.90 \\
\hline \multirow{2}{*}{ 입직원 몰입도 } & 상위 경영자의 관심 & 0.76 & 9.24 \\
\cline { 2 - 4 } & 프로젝트 팀원의 적극성 & 0.84 & 10.12 \\
\hline
\end{tabular}

$x^{2}=104.23, d f=41, p=0.0000, G F I=0.89$, CF $I=0.90$, IFI $=0.90$.

모든 $t$ 값은 $p<0.05$ 에서 유의적으로 요인적재되었음을 나타냄.

\begin{tabular}{c|c|c|c}
\hline 구성개녑 & 항목 & MSC & T값 \\
\hline \multirow{4}{*}{\begin{tabular}{c} 
부서강합정도 \\
\cline { 1 - 3 }
\end{tabular}} & R\&D부서와 생산부서 협조 & 0.91 & 14.60 \\
\cline { 2 - 4 } & 마케텅부서와 R\&ㅁ부서 협조 & 0.94 & 15.26 \\
\cline { 2 - 4 } & 마케팅부서와 생산부서 협조 & 0.75 & 10.78 \\
\cline { 2 - 4 } & 마케팅부서와 디자인 협조 & 0.75 & 10.80 \\
\hline \multirow{3}{*}{ 제품 차별화 } & 완벽한 신제품 & 0.56 & 7.15 \\
\cline { 2 - 4 } & 시장의 주된 변화 가능성 & 0.85 & 12.62 \\
\cline { 2 - 4 } & 국내에 첫 도입 & 0.78 & 11.02 \\
\cline { 2 - 4 } & 독특한 특징 제 공 & 0.81 & 0.81 \\
\hline \multirow{3}{*}{ 신제품 성과 } & 수익성 & 0.64 & 0.64 \\
\cline { 2 - 4 } & 시장점유율 & 0.94 & 0.94 \\
\cline { 2 - 4 } & 판매성과 & 0.96 & 0.96 \\
\cline { 2 - 4 } & & & \\
\hline
\end{tabular}

$x^{2}=95.87, d f=41, p=0.0000, G F I=0.90, C F I=0.95$, IFI $=0.95$.

모든 $\mathrm{t}$ 값은 $\mathrm{p}<0.05$ 에서 유의적으로 요인적재되었음을 나타남.

\section{3 타당성 분석}

새롭게 개발된 설문에 대한 타당성을 검중하기 위해서 본 연구에서는 두 가지 타당성 검중법을 사용하였다. 개념타당성(construct validity)은 측정도구가 실제로 무엇을 측정하였는가 또는 연구자가 측정하고자 하는 추상적인 개념이 실제로 측정도구에 의해서 
적절하게 측정되었는가의 문제로서, 이론적 연구를 하는데 있어서 가장 중요한 타당성이다. 개념타당성은 요인분석을 통해서 검중된다. 모든 요인들의 아이게 값이 허용치인 1.0 을 상희하여야 하는데 각 설문의 요인에 대한 아이겐 값들은 모두 유의수준을 상회하고 있다. 기준타당성(criterion-related validity)은 하나의 속성이나 개넘의 상태에 대한 측정이 미래시점에 있어서의 다른 속성이나 개념의 상태변화를 예측하는 능력을 의미한다. 상관분석의 결과가 유의한 경우 기준타당성을 만족한다고 할 수 있다(강병서 1999). <표 4$4>$ 는 상관관계분석에 대한 결과이다.

<표 4-4> 각 연구단위들간의 상관관계행렬

\begin{tabular}{|c|c|c|c|c|c|c|}
\hline & $\begin{array}{c}\text { 마케팅 } \\
\text { 능력 }\end{array}$ & $\begin{array}{l}\text { 기술 } \\
\text { 눙력 }\end{array}$ & $\begin{array}{l}\text { 임직원 } \\
\text { 몰입도 }\end{array}$ & $\begin{array}{l}\text { 부서간 } \\
\text { 퉁합정도 }\end{array}$ & $\begin{array}{c}\text { 제품 } \\
\text { 차별화 }\end{array}$ & $\begin{array}{c}\text { 신제품 } \\
\text { 성과 }\end{array}$ \\
\hline 마케팅 능력 & 1.000 & & & & & \\
\hline 기술 능력 & $0.490 * *$ & 1.000 & & & & \\
\hline 임직원 몹입도 & $0.429 * *$ & $0.366 * *$ & 1.000 & & & \\
\hline 부서간 통합정도 & $0.394 * *$ & $0.494 * *$ & $0.502 * *$ & 1.000 & & \\
\hline 제품 차별화 & $0.405 * *$ & $0.280 * *$ & $0.272 * *$ & $0.311 * *$ & 1.000 & \\
\hline 신재품 성과 & $0.568 * *$ & $0.356 * *$ & $0.313 * *$ & $0.383 * *$ & $0.454 * *$ & 1.000 \\
\hline
\end{tabular}

1) **: $p<0.01$ 에서 유의함.

2) 대각선 아래는 상관계수, 대각선은 각 구성개녑들의 평균값을 의미함.

\section{4 연구모형의 검중}

LISREL 8.30 을 이용하여, 본 연구의 연구모형(conceptual model)을 검중한 결과 $\mathrm{x}^{2}=$ $10.63, \mathrm{~d} . \mathrm{f}=4, \mathrm{p}$ 값 $=0.027, \mathrm{GFI}=0.98, \mathrm{NFI}=0.96, \mathrm{CFI}=0.97$ 을 갖는 <그림 4-1>와 같은 최적모형이 도출되었다. 이 모델은 구조방정식에서 일반적인 평가기준을 삼는 지표들과 비교할 때, $\mathrm{x}^{2}$ 값에 대한 $\mathrm{p}$ 값은 기준을 충족시키지 않으나. $\mathrm{GFI}$ 와 NFI 값이 0.88 이상이며, $\mathrm{CFI}$ 지수가 0.9 이상이기 때문에 분석에는 무리가 없을 것으로 판단된다(Hair et al., 1995). 
<그림 4-1> 확중모델 분석결과

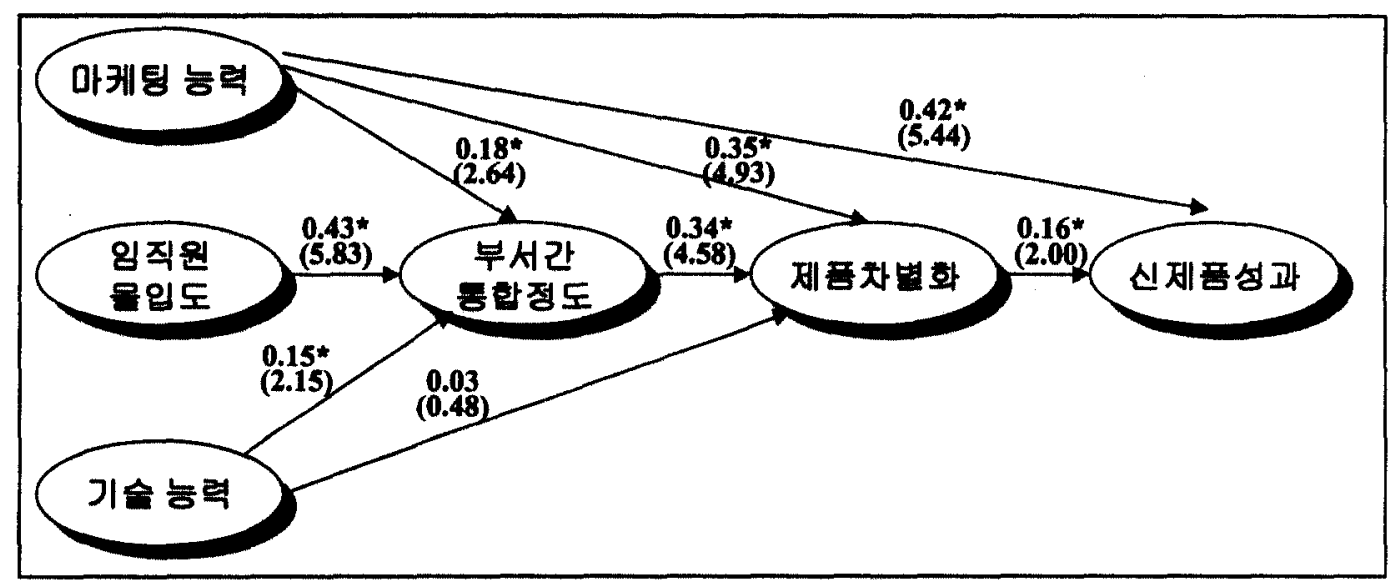

\section{5 연구가설의 검중 및 논의}

\subsection{1 제품 차별화에 관한 가설검중}

NPD 과정에서의 마케팅 능력, 기술 능력, 부서간 퉁합정도, 제품 차별화, 신제품 성과 등 연구단위들간의 관계에 대한 본 연구의 가설을 LISREL 8.30 을 이용하여 분석한 결과를 표로 나타내면 <표 4-5>와 같다.

<표 4-5> 연구가설에 따른 분석결과

\begin{tabular}{c|c|c|c}
\hline 가설 & 경로 & 경로계수 & I t 값 \\
\hline I & 마케텅 능력 $\rightarrow$ 부서간 통합정도 & 0.18 & 2.64 \\
\hline II & 마케팅 눙력 $\rightarrow$ 제품 차별화 & 0.35 & 4.93 \\
\hline III & 마케텅 능력 $\rightarrow$ 신제품 성과 & 0.42 & 5.44 \\
\hline IV & 임직원 몰입도 $\rightarrow$ 부서간 퉁합정도 & 0.43 & 5.83 \\
\hline V & 부서간 통합정도 $\rightarrow$ 제품 차별화 & 0.34 & 4.58 \\
\hline VI & 기술 능력 $\rightarrow$ 부서간 퉁합정도 & 0.15 & 2.15 \\
\hline VII & 기술 눙력 $\rightarrow$ 제품 차별화 & 0.03 & 0.48 \\
\hline VII & 제품 차별화 $\rightarrow$ 신제품 성과 & 0.16 & 2.00 \\
\hline
\end{tabular}

우선, 가설 I을 검중한 결과, 경로계수 값은 $0.18, \mathrm{t}$ 값은 $2.64(\mathrm{p}<0.05)$ 로 나타나 
기업의 마케팅 능력이 부서간 퉁합에 긍정적인 영향을 미치는 것으로 조사되었다(Cooper 1979; Song \& Parry 1994). 둘째, 가설 II 를 검중한 결과, 경로계수 값은 0.35, t 값은 4.93( $p$ < 0.05)으로 나타나 기업의 마케팅 능력이 제품 차별화에 긍정적인 영향을 미치는 것으로 나왔다(Day \& Nedungadi 1994; Song \& Parry 1994, 1997). 셋째, 가설피을 검증한 결과, 경로계수 값이 $0.42, \mathrm{t}$ 값은 $5.44(\mathrm{p}<0.05$ )로 나타나 기업의 마케팅 능력이 신제품 성과에 긍정적인 영향을 미치는 것으로 조사되었다(Calantone, Schmidt, and Song 1996; Cooper 1979). 넷째, 가설IV를 검중한 결과, 경로계수 값이 $0.43, \mathrm{t}$ 값은 5.83 ( $\mathrm{p}<$ $0.05)$ 으로 나타나 임직원의 몰입도가 부서간 퉁합정도에 긍정적인 영향을 미치고 있음을 확인하였다(Griffin \& Hauser 1992, 1993; Zirger \& Maidique 1990). 다섯째, 가설V올 검중한 결과, 경로계수 값은 $0.34, \mathrm{t}$ 값은 4.58 ( $\mathrm{p}<0.05$ )으로 나타나 부서간 붕합이 제품 차별화에 긍정적인 영향을 미치는 것으로 조사되었다(Clark \& Fujimoto 1990; Nonaka 1990). 여섯째, 가설VI을 검중한 결과, 경로계수 값은 $0.15, \mathrm{t}$ 값은 2.15 ( $\mathrm{p}<0.05$ )으로 나타나 기술 능력이 부서간 퉁합정도에 긍정적인 영향을 미치는 것으로 조사되었다(Calanton et al. 1996; Cooper 1979; Song \& Parry 1997).

그러나 가설VI을 검증한 결과, 경로계수 값은 $0.03, \mathrm{t}$ 값은 $0.48(\mathrm{p}>0.05)$ 으로 나타나 기술능력이 제품 차별화에 유의한 영향을 주지 못한 것으로 조사되었다. 따라서 가설VI은 기각되었다. Cooper(1979)와 Song \& Parry(1997)의 선행연구에서 검중된 결과와는 달리 본 연구에서는 국내 화장품 시장의 특성상 생산설비가 표준화되어 있어서 단순한 생산능력만으로는 제품을 차별화시킬 수 없음울 발견하였다. 첨단기술 산업과는 달리 회사간의 제품제조 능력이회사간에 비슷하다는 사실을 알 수 있다. 왜냐하면, 한 회사가 신제품올 시장에 출시하면(market leader/market challenger 의 웅답률이 58.4\%) 골바로 동일 컨셉의 “Me-too" 제품이 출시되기(market follower 의 옹답률- 32.1\%) 때문에 단순히 제조 능력이 우수하다고 해서 제품의 차별화는 가져올 수 없음을 알 수 있었다. 또한 화장품의 소비자 효익에 있어서 기능적 이점(functional benefits)보다는 감성적 이점(emotional benefits)이 더 많은 영향을 주기 때문이라 본다. 예를 들어 립스틱의 경우는 색상이나 발립성에 있어서의 기술적 차이는 소비자로서 그 우위성이나 차이점을 직접 비교하기는 매우 힘들 수 있다. 그러므로 동일 제품일지라도 품평시 상표노출(branded) 테스트냐 상표비노출(blinded) 테스트냐에 따라 결과가 매우 다른 것은 이 때문인 것이다.

\section{5 .2 신제품 성과에 관한 가설검중}

LISREL 8.30 을 이용하여, 가설V四을 검중한 결과, 경로계수 값은 $0.16, \mathrm{t}$ 값은 2.00 (p< 0.05)으로 나타나 제품의 차별화가 신제품 성과에 긍정적인 영향을 미치는 것으로 조사되었다(<표 4-5> 참조). 따라서 가설VI은 채택되었다(Cooper \& Klenschmidt 1987, 1993: Parry \& Song 1994, 1996).

다음으로 각 요인둘간 결합관계에 따라 신제품 성과에 어떠한 영향을 미치는지 알아보기 위해 조절회귀분석(moderating regression analysis;MRA)을 실시하였다. 조절회귀분석은 다음과 같은 3 개의 회귀식을 비교하여 실행할 수 있다.

$Y=a+b_{1} X-\cdots(1)$ 
$Y=a+b_{1} X+b_{2} Z$

$Y=a+b_{1} X+b_{2} Z+b_{3} X Z$

그리고 각각의 회귀모형에서 얻은 $R^{2}$ 값의 중가분을 비교해봄으로써 희귀계수의 유의도를 검정할 수 있다(이훈영. 김근배 1995; 문병준 1999 ; Sharma et al. 1981). 여기서 회귀계수 자체의 유의도 검정에 의해서가 아니고 $\mathrm{R}^{2}$ 증가분에 의해서 검정하는 것은 독립변수간의 다중공선성 때문이다. 본 연구에 사용된 7 개의 독립변수 중 한 변수를 선정하여 이률 $Z$ 변수로 놓고 나머지 6 개의 변수를 번갈아 가면서 $X$ 로 사용하여 조절희귀분석을 실시하였다. 이 결과 잠재성 요인이 준조절변수(quasi moderator)임을 밝힐 수 있었다(<표 4-6> 참조).

<표 4-6> 조절회귀분석 결과

\begin{tabular}{|c|c|c|c|c|c|}
\hline \multirow{2}{*}{ 요 인 } & \multicolumn{4}{|c|}{ 신제품 성과 } & \multirow{2}{*}{ F 값 } \\
\cline { 2 - 5 } & 제한 모형* & $\mathrm{R}^{2}$ & 전체모형* & $\mathrm{R}^{2}$ & \\
\hline 제품차별화 & & & -0.401 & & \multirow{2}{*}{$\begin{array}{l}\text { 9.4*** } \\
x\end{array}$} \\
잠재성 & $0.348 * *$ & 0.250 & 0.276 & \\
\hline
\end{tabular}

*: 표준화된 회귀.계수(Beta)

** : $p<0.01$ 에서 유의함.

*** : $p<0.05$ 에서 유의함.

1. 상호작용의 부가적 영향력을 파악하기 위한 검증은 다음과 같은 두 가지 희거 모형에 대한 F-검중을 하였다.

전체모형 (full model; FM) : $Y=a+b_{1} X Y+b_{2} Z+b_{3} X Z$

축소모형(reduced model; $R M): Y=a+b_{1} X+b_{2} Z$

여기서 $Y=$ 신제품 성과

$\mathrm{X}=$ 임직원 물입정도, 부서간 뽕합정도, 제품차별화

$Z$ = 시장 잠재성

2. $\mathrm{F}=\frac{[\mathrm{SSE}(\text { 축소모형 })-\operatorname{SSE}(\text { 전체모형 })] /(\mathrm{p}-\mathrm{q})}{\mathrm{SSE}(\text { 전체모형 }) /(\mathrm{n}-\mathrm{p}-1)}$

여기서 SSE : 편차제곱의 합

$\mathrm{n}=$ 표본 수

$\mathrm{p}$ : 전체모형의 독립(설명) 변수의 수

$\mathrm{q}$ : 축소모형의 독립(설명) 변수의 수

위의 표를 보면, 제품차별화가 신제품 성과에 영향을 미치고 있음을 알 수 있다. 시장의 잠재성이 매우 큰 시장에 제품을 출시하였울 때, 차별화된 제품은 더욱 신제품 성과에 매우 긍정적인 영향을 미치고 있음을 알 수 있다. 그래서 가설 IX는 채택되었다(Cooper 1979; Song \& Parry 1994).

마지막으로, 가설 $\mathrm{X}$ 을 검중하기 위하여 기업의 마케텅 활동을 평균값(4.67)을 중심으로 평균이상의 집단 $1 \quad(n=83)$ 과 평균이하의 집단 $2 \quad(n=76)$ 로 분류하여 신제품 성과와의 
상관관계분석을 실시하였다(<표 4-7> 참조).

<표 4-7> 마케팅 활동에 따른 신제품 성과와의 상관관계

\begin{tabular}{c|c|c}
\hline & $\begin{array}{c}\text { 마케팅 활동 } \\
\text { (집단 } 1 ; \mathrm{n}=83)\end{array}$ & $\begin{array}{c}\text { 마케텅 활동 } \\
\text { (집단 } 2 ; \mathrm{n}=76)\end{array}$ \\
\hline 제품 차별화 & $0.458 *$ & 0.148 \\
\hline
\end{tabular}

*: $\mathrm{p}<0.01$ 에서 유의함.

기업이 제품을 시장에 출시한 후, 마케팅에 노력을 집중하는 집단이 차별화된 제품을 경쟁사보다 더욱 강화시켜 신제품 성과에 더 많은 영향을 미치고 있음을 알 수 있다. 그래서 가설 X은 채택되었다(Song \& Parry 1997).

\section{5. 결론 및 시사점}

\section{1 결론}

본 연구논문은, Day \& Wensley 의 SPP(Source-Position-Performance) 연구모형울 바탕으로 국내 화장품시장을 중심으로 설문 조사한 결과, 11 개 기업에서 충 159 부룰 수집하여 연구 모형 및 연구 가설을 검중하였다. 요인분석을 한 결과 41 개 변수를 7 개요인(constructs)으로 분류할 수 있었다. 그리고 본 연구 모형을 토대로 설정한 가설을 검중한 결과 다옴과 같은 사실을 밚혀냈다.

제품이 출시되기 전에 철저한 시장 톡성 및 동향을 파악하여 제품을 만들어야 한다는 사실이다. 기술 눙력이 회사마다 평준화되어 있는 상황에서 무엇보다 필요한 것온 정확한 소비자 조사 및 이를 바탕으로 한 신제품개발이다. 또한 신제품개발 과정에서 최고경영자 및 마케텅 담당자들은 주관적인 판단보다는 기업의 마케팅 능력에 따른 객관적인 판단에 따라 행동해야 하며, 경쟁사보다 떠어난 제품을 만들 수 있도톡 기업내 부서간 커뮤니케이션 및 자원들이 잘 활용될 수 있는 분위기를 조성해 주어야 한다. 그리고 마케팅 능력 및 임직원 몰입도는 부서간 통합을 매개로 하여 제품을 차별화시키는데 유의한 영향을 미치고 있옴을 밝혀냈다.

제품이 출시 된 후에는 소비자의 욕구에 맞는 차별화된 제품일수록 성공할 수 있었다. 그렇지만 차별화된 제품이 잠재성이 큰 시장에 뛰어들 때 성공할 가능성이 더욱 높아지고, 기업이 마케팅 활동을 활발하게 수행할 때 차별화된 제품을 더욱 더 성공시킬 수 있는 요인임이 밝혀졌다. 특히 화장품시장에서는 제품 및 브랜드는 마케팅에 의해 더욱 차별화시킬 수 있다는 사실이다. 단순한 제품에 생명력을 불어넣는 것이 마케터의 역할이다. 
기업은 단순히 제품만을 파는 것이 아니라 소비자들에게 제품이상의 것을 판다. 그래서 소비자의 마음속에 정확하게 자사 제품을 포지셔닝하는 것이 무엇보다 중요하다

본 연구논문은 신제품의 개념 및 전반젹인 신제품 개발 프로세스룰 기업의 측면에서 살펴보았다. 이 논문이 시사하는 바는 우선, 성숙기에 접어든 화장품시장에서 신제품을 성공시키기 위해서 무엇보다 기업의 마케팅 능력이 뛰어나야 한다는 사실이다. 그리고 상위 경영자 및 마케텅 담당중역이 적극적인 기업의 비전을 제시하고 부서간 통합이 원활하게 유지될 수 있도록 유도해 주어야 하며 제품을 출시한 이후에도 신제품이 시장을 리드할 수 있도록 마케팅 활동을 끓임없이 해 주어야 한다는 점이다.

\section{2 연구의 한계 및 향후 과제}

본 연구논문은 위에서 언급했둣이 많은 시사점을 제시해 주고 있지만, 다음과 같은 한계점을 가지고 있다. 먼저, 선행 연구논문에서 시장환경(예를 들면, 시장의 잠재성, 경쟁 정도)이 신제품개발 프로세스에 유의한 영향을 미친다는 결과가 있는데 본 연구논문에서는 신제품개발 프로세스에 기업내 환경에 주로 초점이 맞춰져 있었다는 사실이다.

둘째, 기업의 임직원 몰입도가 신제품 출시 후에도 신제품 성과에 영향을 미첬다는 선행 연구논문에서 불 수 있었지만, 본 연구논문에서는 마케팅 활동에만 초점을 맞추어서 좀 더 포괄적인 연구가 진행되지 못했다는 점이 아섭다.

셋째, 본 연구의 신제품 성과를 측정하는 요인들을 크게 세 가지-수익성, 시장 점유율, 판매 성과로 보아 웅답자의 주관적인 관점에서 7 점 척도로 측정하였다. 주관적인 관점은 편견(bias)으로 인하여 결과분석이 희석될 우려가 있다(이훈영. 김근배 1995). 또한 경쟁이 치열하고 성과자료롤 기밀시하는 산업의 븍성상 객관적인 자료를 구하기가 어려욌으며, 신제품 성과측면도 기업마다 상이하기 때문에 간접적으로 신제품 성과를 측정할 수밖에 없었다.

넷째, 본 연구논문은 첨단기술을 기반으로 하는 기업에 적용되는데 어려움이 있다. 첨단기술 산업은 기술늉력을 바탕으로 전개되며 비용측면이 매우 강조되고 있기 때문이다. 그리고 가격에 매우 민감하게 반옹하는 산업에서도 본 연구결과를 적용하는데 한계가 있다. 본 연구논문은 화장품시장에서 가격차별화가 신제품 성과에 매우 미비한 영향을 미칠 것이라고 생각하였기 때문에 가격 측면에서는 살펴보지 않았다. 오히려 가격이 저렴하면 품질이 양호하지 않을 것이라는 것이 소비자의 일반적 사고이기 때문이다.

다섯째, 본 연구논문은 국내 화장품 기업만을 대상으로 하였다. 하지만 국내에 들어와 있는 외국계 화장품 기업과의 핵심 성공요인을 서로 비교. 연구해 본다면 좀더 완벽한 연구모형을 일반화시킬 수 있을 것이다. 


\section{<참고 문헌>}

강병서 (1999), 「인과분석올 위한 연구방법론」, 서울 : 무역경영사.

김원수 (1991), 「신제품개발론」, 경문사.

서성한 (1998), 「소비자행동의 이해」, 박영사

- 이영회 (1999), 「마케텅의 이해-이론과 실제」, 삼우사.

- 박기안 (1998), $「$ 마케팅론」, 법경사

신건철 외 편역 (1997), 「신제품개발 7 가지 성공비결」, 21 북스새날.

김종배 (1991), “신제품의 성과에 영향을 미치는 요인에 관한 실증적 연구” , 연세대학교 박사학위 논문.

김홍범 (1986), “신제품의 시장성과 및 결정요인” , 한국과학기술원 박사학위논문.

노전표 (1998), “하이테크 신제품 혁신 성공요인에 관한 연구, 한국경영학희, 98 년도 춘계학술발표논문집, pp. 373-375.

이훈영. 김근배 (1995), "금용신상품 성공요인과 매개요인에 관한 실중연구" , 경영학연구, 제 24 권 제 1 호, pp. 81-109.

문병준 (1999), " 기업의 핵심역량과 신제품개발 뵥성간의 관계: 네스티드 모델들의 비교 분석", 마케팅연구, 제 14 권 제 2 호, pp. 95-111.

Booz, Allen and Hamilton (1982), New Products Management for the 1980s, Booz, Allen and Hamilton inc.

Clark, Kim B. and Takahiro Fujimoto (1991), Product Development Performance, Boston: Harvard Business School Press.

Crawford, C. Merle (1991), New Products Management, 3th Edition, Richard D. Irwin, Inc.

Engel James F., Roger D. Blackwell, and Paul W. Miniard (1995), Consumer behavior, 8th Edition, The Dryden Press.

Hair, Joseph F, Rolph E. Anderson, Ronald L. Tahtam and William C. Black (1995), Multivariate Data Analysis with Readings(4th ed), Englewood Cliffs: Prentice Hall.

Imai, Ken-ichi, Ikujiro Nonaka, and Hirotaka Takeuchi (1985), "Managing the NPD Process: How Japanese Companies Learn and Unlean", in The Uneasy Alliance, Kim B. Clark, Robert H. Hayes, and C. Lorenz (1985), eds, Boston: Harvard Business School Press.

Pfeffer, Jeffrey and Gerald R. Salancik (1978), The External Control of Organizations: A Resource Dependence Perspective, New York:Harper and Row.

Scheuing, Eberhard E. (1989), New Product Management, Merrill Publishing Co.

Thomas D. Kuczmarski (1988), Managing New Products, Prentice-Hall.

Urban, Glen L. and John R. Hauser (1993), Design and Marketing of New Products, Englewood Cliffs, NJ: Prentice Hall. 
Wind, Yoram, Vijay Mahajan, and Barry L., Bayless (1990), The Role of New Product Models in Supporting and Improving the New Product Development Process, Some Preliminary Results, Cambridge, MA: The Marketing Science Institute.

Wind, J. and Vijay Mahajan (1988), "New Product Development Game", Harvard Business Review, pp. 137-146.

Bernard J. Jaworski and Ajay K. Kohli (1993), "Market Orientation: Antecedents and Consequences", Journal of Marketing, Vol. 57(July), pp. 53-70.

Calantone, Roger J. and Robert G. Cooper (1981), "New Product Scenarios: Prospects for Success", Journal of Marketing, Vol. 45(Spring), pp. 48-60.

Jeffrey B. Schmidt, and X. Michael Song (1996), "Controllable Factors of New

Product Success: A Cross-National Comparison", Institute for Operational Research and the Management Sciences, Vol. 15(4), pp. 341-358.

Clark, Kim B. and Takahiro Fujimoto (1990), "The Power of Product Integrity", Harvard Business Review, Vol. 68(6), pp 107-118.

and Steven Wheelwright (1992), "Organizing and Leading 'Heavyweight' Development

Teams", California Management Review, Vol. 34(3), pp. 9-28.

Cooper (1979a), "The Dimensions of Industrial New Product Success and Failure", Journal of Marketing, Vol. 43(Summer), pp. 93-103.

(1986), "New Product Performance and Product Innovation Strategy", Research

Management, May-June, p. 17.

and E. J. Kleinschmidt (1986), "An Investigation Into the New Product Process-Steps,

Deficiencies, and Impact", Journal of Product Innovation Management, Vol. 3(March), pp. 71-85.

(1987), "What make a New Product a Winner: Success

Factors at the Project Level", $R \& D$ Management, Vol. 17, pp. 175-189.

(1988), "Resource Allocation in the New Product Process",

Industrial Marketing Management, pp. 249-262.

(1993), "Major New Products: What Distinguishes the

Winners in the Chemical Industry?", Journal of Product Innovation Management, Vol. 10(March), pp. 240-251.

Day, George S. and Robin Wensley (1988), "Assessing Advantage : A Framework for Diagnosing Competitive Superiority", Journal of Marketing, Vol. 52(April), pp. 1-20. and Parakash Nedungadi (1994), "Managerial Representations of Competitive Advantage", Journal of Marketing, Vol. 58(April), pp.31-44.

Gatignon, Hurbert and Jean-Marc Xuereb (1997), "Strategic Orientation of the Firm and New Product Performance", Journal of Marketing Research, Vol. 43(2), pp. 77-90.

Griffin, Abbie and John R. Hauser (1992), "Patterns of Communication Among Marketing, Engineering and Manufacturing- A Comparison Between Two New Product Teams", Management Science, Vol. 38(March), pp. 360-373.

12(Winter), pp. 1-27.

(1993), "The Voice of the Customer", Marketing Science, Vol.

Han, Jin K., Namwoon Kim, and Rajendra K. Srivastava (1998), "Market Orientation and Organizational Performance: Is Innovation a Missing Link?", Journal of Marketing, Vol. 62(October), pp. 30-45.

Maidique, Modesto A. and Billie Jo Zirger (1984), "A Study of Success and Failure in Product innovation: The Case of the U.S. Electronics Industry", IEEE Transactions on Engineering 
(1990), " Model of NPD: An Empirical Test",

Management Science, Vol. 36, pp. 867-883.

Nonaka (1990), "Redundant, Overlapping Organization: A Japanese Approach to Managing the Innovation Process", California Management Review, Vol. 30(3), pp. 52-73.

Olson, Eric M; Walker, Orville C Jr; Ruekert, Robert W (1995), "Organizing for effective new product development: The Moderating role of Product Innovativeness, Journal of Marketing, Vol. 59(January), pp. 48-62.

Park, Myung-Ho and J. Barry Mason (1990), "Toward an Integrated Model of the Determinants of Business Performance: A Business-Level Strategic Planning Perspective", Research in Marketing, Vol. 10, pp.

Prahalad, C. K. and Gary Harmel (1990), "The Core Competence of the Corporation", Harvard Business Review, Vol. 68(May/June), pp. 79-91.

Rubenstein, Chakrabarti, R. O'Keefe, William E. Souder, and C. Young (1976), "Factors Influencing Innovation Success at the Project Level", Research Policy, Vol. 10(May), pp. 15-20.

Ruekert, Robert W. and Orville C. Walker (1987), "Marketing's Integration with Other Functional Units: A Conceptual Framework and Empirical Evidence", Journal of Marketing, Vol. 51(January), pp. $1-19$.

Sharma, Subash, Richard, M. Durand and Oded Gur-Arie (1981), "Identification and Analysis of Moderator Variables", Journal of Marketing Research, Vol. 18(August), pp. 291-300.

Song, X. Michael and Mark E. Parry (1994), "The Dimensions of Industrial New Product Success and Failure in State Enterprises in the People's Republic of China", Journal of Product Innovation Management, Vol. 11(March), pp. 105-118. 